\title{
Attitudes of Undergraduate Students Towards Self-employment in Yemen Public Universities
}

\author{
AL-Qadasi Nabil Abdullah Abdo Saeed*, Zhang Gongyi \\ School of Management, Jilin University, PO box 130022, Changchun, Jilin, China \\ *Corresponding author AL-Qadasi Nabil can be contacted at: alnabil1976@gmail.com
}

\begin{abstract}
To the best of the authors' knowledge, the intention of undergraduate students towards self-employment has not been yet studied in Yemen. We aimed to study the intentions of undergraduate students towards self-employment as a career choice. Since most literature agrees that future intention towards self-employment can be determined by using the Theory of Reasoned Action (TRA), this theory is used as a theoretical framework in this study. A questionnaire survey was completed by a random sample $(n=451)$ of university students, undergraduate level, at one of the major public universities in Yemen. Results were based on descriptive analysis and multivariate statistical analysis including crosstabs, bivariate correlation and binary logistic regressions. Results of correlation test indicates that there are positive and significant correlations between dependent variable students' intention to be self-employed and independent variables; entrepreneurial awareness $(r=.338, n=401, \mathrm{P}<.00)$ and attitude $(r$ $=.569, n=401, \mathrm{P}<.00)$, whereas social norms variable, has derived low and not significant correlation value $(r$ $=.066, n=373, \mathrm{P}>.20)$. Binary logistic regression results showed that both variables, entrepreneurial awareness $(\beta=2.154, \mathrm{p}<0.005)$ and attitude $(\beta=3.117, \mathrm{p}<0.005)$, are significantly correlated with the students' intention to start a business, whereas there is no significant correlation between the social norms and the students' intention to start a business $(\beta=-0.153, \mathrm{p}>0.744)$. Our study suggests that providing entrepreneurial capabilities among citizens may improve social norms toward entrepreneurship. The study also makes a valuable contribution to the under-researched context of Yemen entrepreneurship.
\end{abstract}

Keywords: Self-employment intention, Undergraduate students, Yemen, Theory of Reasoned Action.

DOI: $10.7176 /$ RHSS/10-2-08

Publication date: January $31^{\text {st }} 2020$

\section{Introduction}

Entrepreneurship is a key factor for economic development, it is perceived as essential for the advancement of economic growth both in developed and emerging economies (Harshana K., 2016; Stel et al., 2005). As one of the basic impulsive forces of economic development, entrepreneurship plus small and new firms have contributed significantly for achieving economic growth, high employment, strong job opportunity creation, positive social development and providing support to local economies. Thus, developing countries like Yemen, encourage university students to be involved in entrepreneurial activity and consider entrepreneurship as a career of choice. It is commonly known that in the future, undergraduates' students are an important source of nascent entrepreneurship. Fostering entrepreneurship among undergraduates' students has become an important topic among entrepreneurship researchers. The university is an institution that students pass on towards working life. Recently, graduates' unemployment problems have gradually become a social problem. It represents a challenging task for the government, where the persistent gap between the supply and demand in the labor market will lead to a higher unemployment rate over the coming years, which leads to an even worst situation. The government has to take the initiative to address this issue by instilling entrepreneurial spirit among university students and to make entrepreneurship subject compulsory to all students regardless of their field of study. Entrepreneurship is considered as an important strategy to sustainability of the country's economic stability and growth, employment, as well as a solution to the excessive number of universities graduates and social problems (Maria, S. and Allam, H., 2019; Reyad et al., 2018; Debus et al., 2017; Adusei, 2016). Because of this crucial role played by entrepreneurship, it is important to look at the view of the university students and to have in-depth research and concrete data on undergraduate students' entrepreneurship to understand the factors that influence their intentions to be self-employment or entrepreneurship effort. Therefore, the current study has three objectives: first, to know the level of entrepreneurial awareness and knowledge among undergraduate students. Secondly, to identify the attitude of undergraduate students toward self-employment as a career choice. Thirdly, to study the influences of the social norms on undergraduate students' intention to launch a new venture. The remaining of this article is structured as follows: section one provides a brief review of the literature and develops hypotheses. Section two 
provides details about sample, measurement and methods. Section three results. Section four findings and discussion. Finally, the article ends with summary conclusions.

\section{Literature Review and Hypotheses Development}

Extant literature suggests that many factors are playing a major role on influencing and stimulating university students' intention to launch a new venture (Kristiansen and Indarti, 2004; Liñán et al., 2011; Aloulou, 2016; Ting et al., 2017; AL-Shammari and Weleed, 2018). The Theory of Reasoned Action (TRA) by (Ajzen and Fishbein, 1980) considered as an important model to measure the individuals' behavior (Peslak A., et al., 2012). It suggests that behavioral intent is derived from two factors which are the attitude towards behavior and subjective norms. Based on the TRA model there are two main influencing factors to stimulate the students' intention to be selfemployed: i) students' attitude ii) and social norms (or perceived social pressure associated with the behavior). Where the attitude is influenced by the students' entrepreneurial awareness and knowledge. Accordingly, the proposed and modified model is adopted from Ajzen and Fishbein's (1980) TRA framework is presented in (Figure $1)$.

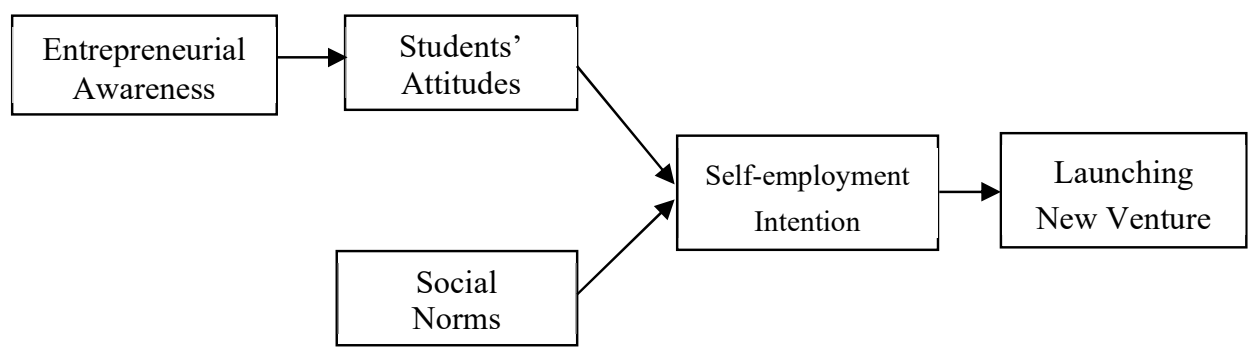

\subsection{Entrepreneurial Intention}

Figure 1| Proposed Theoretical Framework

Entrepreneurial intention or self-employment intention is one of the basic concepts when studying entrepreneurship, it's considered synonymous with entrepreneurship. Most of the studies use entrepreneurial intention as a proxy for measuring the level of entrepreneurship activity.

Entrepreneurial intention has been defined in different ways, such as the intention of a person to set up a new business venture in the future (Thompson, 2009), the intention to own a business (Grant, 1996) and as the intention to be self-employed (Douglas and Shepherd, 2002). Entrepreneurial intention has a psychological nature, according to (Krueger et al., 2000) the intention has proven as the best predictor of an individual's planned behavior, especially when the behavior is rare and hard to observe or involves an unpredictable amount of time. The stronger an individual's intention to engage a given behavior, the more likely to perform this behavior (Maresch et al., 2016). In our context, the students' intention to be self-employed is defined as the subjective probability to launch a new business. This variable is used as a dependent variable to test the influences of the attitudes and social norms on the potential launch of new businesses by the students as a source of earnings and livelihood.

\subsection{Entrepreneurial Awareness}

The entrepreneurial awareness in this study is defined as an outcome of the received formal and informal entrepreneurial learning. The entrepreneurship education has an impact on raising the awareness and knowledge level about entrepreneurship as a viable career path which in turn link with the individual's motivation to engage in entrepreneurial activity and his decision to become an entrepreneur. According to (Zheng Li and Yang Liu, 2011), entrepreneurship education is important for university students to raise their employment performance through the cultivation of entrepreneurship, innovation and entrepreneurial skills. The knowledge on business development, administration and management as well as acquiring the necessary skills, attitude and behaviors will lead into creating positive attitudes towards entrepreneurship, which has a significant impact on the youth's decision to become an entrepreneur (Malebana, 2017).

The attitude and knowledge of entrepreneurship are likely to shape the inclination of university students to start their own business in the future (Wang and Wong, 2004). Knowing their attitude, awareness and aspirations towards entrepreneurship is a crucial action that should be taken before any intervention or initiative to raise the entrepreneurial inspiration among young people. Efforts aimed at increasing the awareness about entrepreneurship, can also enhance the importance of entrepreneurship in society by developing social awareness about 
entrepreneurship (Gnyawali and Fogel, 1994; North and Smallbone, 2006). This variable is used in this study as an independent variable to know the students' level of entrepreneurial awareness as an external factor on the students' attitude to be self-employed. Thus, we hypothesize:

H1: there is a good entrepreneurial awareness among undergraduate students.

\subsection{Attitude Toward Entrepreneurship}

Attitude towards entrepreneurship in this study refers to the students' feeling of favorableness or unfavorableness towards self-employment as a career of choice. According to Ajzen and Fishbein's (1980) TRA, the construct of attitude is determined as salient beliefs that starting own business will lead to certain outcomes and evaluation for these outcomes. Individuals with a strong attitude and attitudinal tendencies towards the expected value of entrepreneurship are more likely to have a higher level of entrepreneurial intention. Several studies identified a number of positive expected or valued outcomes of entrepreneurial behavior such as valuation of money, autonomy, authority, challenge, change, personal satisfaction and personal quality of life (Davidsson, 1995; Kolvereid, 1996a, 1996b; Krueger et al., 2000; Kolvereid and Isaksen, 2006; Van Gelderen et al., 2008; Schwarz et al., 2009; Engle et al. 2010; Zhang et al., 2015). Based on the findings of these studies, individuals are more likely to view entrepreneurship as a viable career choice when they believe that it will result in achieving outcomes that they value. Therefore, the second hypothesis is as follows:

$\mathrm{H} 2$ : undergraduate students have a positive attitude toward self-employment.

\subsection{Social Norms}

Social/Subjective norms are the most important factor of TRA, which refers to the perceived social and cultural pressure felt by an individual to perform or not perform a specific behavior (Kolvereid, 1996b). The opinions from family members, close friends, relatives, business experts and even advisors such as academics/consultants are likely to encourage or discourage potential entrepreneurial behaviour of undergraduate students, especially when they have little entrepreneurial experience. Several studies find a significant relationship between social norms and entrepreneurial intention (Kolveried, 1996b; Tkachev and Kolvereid, 1999; Kolveried and Isaksen, 2006), in contrast, other studies do not support this finding (Krueger et al., 2000; Autio et al., 2001; Liñán and Chen, 2009). In their study (Engle et al., 2010), found social norms to be significant concerning entrepreneurial intentions in twelve-countries. Thus, the third hypothesis would be:

H3: social norms have significant influences on undergraduate students' intention to launch a new venture.

\section{Methodology and procedures}

\subsection{Participants}

This research has been developed with the purpose of predicting the potential of launching a new venture by university students undergraduate level through identifying their intentions towards self-employment. The present study followed the quantitative method, allowing a large numbers of participants for data collection. By the time of the survey, October 2019, the university had 14 different humanitarian and scientific schools. Randomly 7 schools $(50 \%)$ were selected to be considered as the research population it is a school of business, economics, law, sciences, computer \& IT, agriculture and art. The sample was determined in accordance with (95\%) of confidence interval by using the following formula, $\left(n=\pi(1-\pi) z^{2} / e^{2}\right)$ the minimum sample size of 385 respondents has been calculated for this study. Given the assumptions $n=$ sample size, $\pi=$ estimated variability in the population $(0.5)$, $z=$ standard error associated with the level of confidence (1.96), and $e=$ acceptable error (0.05), the sample size is estimated by $(0.5)(0.5)(1.96)^{2} /(0.05)^{2}=384.16$. The final sample size is determined to be 481 respondents as $25 \%$ was included as contingency percent $(385 \times 1.25=481)$ (Yemane, 1967).

3.2 Measures

Entrepreneurial awareness. To measure the level of entrepreneurial awareness and knowledge, two questions were designed to gather information about university students' knowledge related to entrepreneurship concept and extent of their awareness of entrepreneurial activity. The first was a simple yes/no question intended to determine whether they had heard of the entrepreneurship concept: "Have you ever heard or read about entrepreneurship?". The second one, is a contingency question to check if the respondents have or have not acquired the right knowledge about entrepreneurship with four different statements about entrepreneurship and the identical response of yes/no: "It doesn't require an innovation/risk", "It requires substantial financial resources", "It doesn't play a role in reducing unemployment" and "It doesn't require the existence of new/unexploited opportunities". 
Attitude toward self-employment. To determine the attitude toward self-employment as a career option, three questions were designed. The first and second questions were developed with three points scale question to measure the undergraduate students' perception toward entrepreneurship as a proper career option for them and others "Self-employment is a good career choice for you" and "Encouraging others towards self-employment". The third dichotomous question is developed to check who is already have their own business or is part of one, this is to avoid asking the students about the future intention towards being self-employed if they are already selfemployed "Are you self-employed?".

Entrepreneurial intention. To measure undergraduate students' intention toward self-employment two questions were designed. The first one was yes/no question developed to know who intent to start his own business in the future "Do you intend to launch your own business in the future?". The second one was a multi-choice question developed to be a contingency question to explore university students' motivation to be self-employment and start a business e.g. "There are good opportunities in the local market", "I possess the experience and knowledge to start and manage a business" and "The financial return of the businesses is high".

Social norms. To know the influences of social norms on undergraduate students' intention to launch their own business, two questions were asked: "If you decide to set up your own business, to what extent the people around you affirm that idea?" and "To what extent the people around you affect the decision on establishing your own business?". The first question addresses students who are not self-employed, whereas the second question addresses students who already have their own business or is part of one. The two questions are matrix because the answer options are identical for six different social influential groups such as family members (mother, father, brother, and sister), close friends, colleagues, close relatives (uncle, aunt), business experts and advisors (academic and consultants). These two questions have been developed with three points scale. The respondents' rating rages between (1) the value of "significant influence"; (2) is "slight influence" and (3) the value of "no influence". Once administered, the findings were statistically analysed by using SPSS (Statistical Package for the Social Sciences). Simple descriptive statistics techniques were used to test hypotheses and achieve the research objectives, frequencies, crosstabs, bivariate correlations and binary logistic regression (Norusis, 2006).

\section{Result}

\subsection{Reliability test}

The reliability analysis of Cronbach's alpha is used to measure the internal consistency of scales items. The analysis shows that the Cronbach's alpha results for internal consistency of entrepreneurial awareness, attitude and social norms were $(0.877),(0.729)$ and $(0.615)$ respectively, which are good and acceptable values to go ahead in this study.

\subsection{Demographic characteristics}

A total of 454 (out of 481 distributed questionnaire, 3 incorrectly completed) students participated in the study making a response rate of (94\%) of which $378(83.8 \%)$ male and $73(16.2 \%)$ female students. In terms of age, 85 were missing answers representing (18.8\%). However, $(81.2 \%)$ answered the age question, 138 represents $(30,6 \%)$ were in the age category $(17-26$ years), 219 of the respondent were in the age category $(22-26$ years) representing (48.6\%), while 9 of the respondent were in the age category (27 - 31 years) which represents $(2 \%)$. These statistics means respondents' ages ranged from (17 - 31) years old which falls in the youth category (Global Entrepreneurship Monitor (GEM) Report 2018/2019). A total of 220 (48.8\%) respondents were business and economics programms, $231(51.2 \%)$ were from diverse programms such as law, sciences, computer \& IT, agriculture and art. In terms of year of study, 132 represents $(29.3 \%)$ were first-year-students, 105 represents $(23.3 \%)$ were second-year-students, 108 represents $(23.9 \%)$ were third-year-students and 106 represents $(23.5 \%)$ were final-year-students (see Table 1). 
Table 1| Demographic characteristics $(n=451)$

\begin{tabular}{|c|c|c|c|}
\hline Characteristics & Category & Frequenc & Percentage \\
\hline \multirow[t]{2}{*}{ Gender } & Male & 378 & 83.8 \\
\hline & Female & 73 & 16.2 \\
\hline \multirow[t]{4}{*}{ Age group } & (17-21 Years) & 138 & 30.6 \\
\hline & (22-26 Years) & 219 & 48.6 \\
\hline & (27-31 Years) & 9 & 2 \\
\hline & Missing & 85 & 18.8 \\
\hline \multirow[t]{2}{*}{ Field of study } & Business and Economics & 220 & 48.8 \\
\hline & Non-business and & 231 & 51.2 \\
\hline \multirow[t]{4}{*}{ Year of study } & $1^{\text {st }}$ year & 132 & 29.3 \\
\hline & $2^{\text {nd }}$ year & 105 & 23.3 \\
\hline & $3^{\text {rd }}$ year & 108 & 23.9 \\
\hline & $4^{\text {th }}$ year & 106 & 23.5 \\
\hline
\end{tabular}

\subsection{The level of entrepreneurial awareness}

As per (Table 2 ) only 148 students (32.8\%) indicate that they have heard or read about the entrepreneurship concept whilst the majority of $303(67.2 \%)$ students indicate that they don't have any knowledge.

Table 2| Entrepreneurial awareness $(n=451)$

\begin{tabular}{|c|c|c|}
\hline \multicolumn{3}{|c|}{ Have you ever heard or read about entrepreneurship? } \\
\hline & Frequency & Percentage $(\%)$ \\
\hline Yes & 148 & 32.8 \\
\hline No & 303 & 67.2 \\
\hline Total & 451 & 100 \\
\hline
\end{tabular}

To test the knowledge of 148 respondents who indicate that they were aware of the entrepreneurship, four statements about entrepreneurship have been developed and the students were requested to answer "Yes" if the statement is applicable on entrepreneurship and "NO" if it is not applicable. As for the results in (Table 3), (83.8\%) of the respondents believe that these two statements "it doesn't require an innovation/risk" and "it doesn't require an existence of new/unexploited opportunity" don't apply to the entrepreneurship, and only (36.5\%) don't believe that "entrepreneurship requires substantial financial resources", where the majority (91.9\%) don't agree that the "entrepreneurship doesn't play a role in reducing unemployment".

Table 3| Respondents' awareness about entrepreneurship $(n=148)$

\begin{tabular}{ccccccccc}
\hline \multicolumn{2}{c}{$\begin{array}{c}\text { It doesn't require } \\
\text { an innovation/risk }\end{array}$} & $\begin{array}{c}\text { It requires } \\
\text { substantial financial } \\
\text { resources }\end{array}$ & $\begin{array}{l}\text { It doesn't play a } \\
\text { role in reducing } \\
\text { unemployment }\end{array}$ & $\begin{array}{c}\text { It doesn't require the } \\
\text { existence of new } \\
\text { /unexploited } \\
\text { opportunities }\end{array}$ \\
\hline Fes & Frequency & $\%$ & Frequency & $\%$ & Frequency & $\%$ & Frequency & $\%$ \\
No & 23 & 15.5 & 94 & 63.5 & 11 & 7.4 & 23 & 15.5 \\
Missed & 124 & 83.8 & 54 & 36.5 & 136 & 91.9 & 124 & 83.8 \\
\hline
\end{tabular}

The four statements have been weighted with $100 \%$, which means that every statement is carrying the weight $(25 \%)$ of awareness. Accordingly, only (19.7\%) from the respondents have succeeded to answer correctly to four statements $(100 \%),(62.6 \%)$ to three statements $(75 \%),(14.3 \%)$ to two statements $(50 \%)$, and $(2.7 \%)$ to one statement $(25 \%)$. In which, the majority $(82.3 \%)$ succeeded to answer correctly at least to three statements. In accordance with this, it is concluded that most of the respondents who knew the entrepreneurship concept are acquiring a good level of entrepreneurial awareness. (Table 4) shows the frequencies and percentages of the respondents' level of entrepreneurial awareness. 
Table 4| Respondents' level of entrepreneurial awareness $(n=147)$

\begin{tabular}{lccc}
\hline & Frequency & Percentage (\%) & $\begin{array}{c}\text { Cumulative } \\
\text { Percent }\end{array}$ \\
\hline $\begin{array}{l}\text { Answered correctly to four } \\
\text { statements }\end{array}$ & 29 & 19.7 & 19.7 \\
$\begin{array}{l}\text { Answered correctly to three } \\
\text { statements }\end{array}$ & 92 & 62.6 & 82.3 \\
$\begin{array}{l}\text { Answered correctly to two } \\
\text { statements }\end{array}$ & 21 & 14.3 & 96.9 \\
$\begin{array}{l}\text { Answered correctly to one } \\
\text { statement } \\
\text { Incorrectly answered }\end{array}$ & 4 & 2.7 & 99.3 \\
\hline
\end{tabular}

Based on the results shown above, only (32.6\%) of the students indicated that they have heard or read about entrepreneurship and from this percentage $(82.3 \%)$ have succeeded to answer correctly to three statements (weighted $25 \%$ per statement) about entrepreneurship (weighted $25 \%$ per statement) which means that only $(26.8 \%)$ of all respondents have indicated that they demonstrated a good level of entrepreneurial awareness. Thus hypothesis $\mathrm{H} 1$ can't be rejected, there is insufficient evidence to suggest that there is good entrepreneurial awareness among undergraduate students.

\subsection{Attitude toward self-employment}

To understand the students' attitudes towards self-employment two questions were developed with three points scale, the respondents' rating ranges between (1) the value of "positive"; (2) is "moderate" and (3) the value of "negative" (see Table 5).

Table 5| Respondents' attitude towards self-employment $(n=450)$

\begin{tabular}{|c|c|c|c|c|}
\hline & \multicolumn{2}{|c|}{$\begin{array}{l}\text { Self-employment is a good } \\
\text { career choice for you }\end{array}$} & \multicolumn{2}{|c|}{$\begin{array}{l}\text { Encouraging others towards } \\
\text { self-employment }\end{array}$} \\
\hline & Frequency & $\begin{array}{c}\text { Percentage } \\
\%\end{array}$ & $\begin{array}{c}\text { Frequenc } \\
\mathrm{y}\end{array}$ & Percentage $\%$ \\
\hline 1- Agree & 273 & 60.7 & 359 & 79.8 \\
\hline $\begin{array}{l}\text { 2- Neither agree nor } \\
\text { disagree }\end{array}$ & 165 & 36.7 & 84 & 18.7 \\
\hline 3- Disagree & 12 & 2.7 & 7 & 1.6 \\
\hline Mean & \multicolumn{2}{|c|}{1.4200} & \multicolumn{2}{|r|}{1.2178} \\
\hline Median & \multicolumn{2}{|c|}{1.0000} & \multicolumn{2}{|r|}{1.0000} \\
\hline Mode & \multicolumn{2}{|c|}{1.00} & \multicolumn{2}{|r|}{1.00} \\
\hline Std. Deviation & \multicolumn{2}{|c|}{.54552} & \multicolumn{2}{|r|}{.44934} \\
\hline Minimum & \multicolumn{2}{|c|}{1.00} & \multicolumn{2}{|r|}{1.00} \\
\hline Maximum & \multicolumn{2}{|c|}{3.00} & \multicolumn{2}{|r|}{3.00} \\
\hline Average Mean & \\
\hline Average Median & \multicolumn{4}{|c|}{1.0000} \\
\hline Average Mode & \multicolumn{4}{|c|}{1.00} \\
\hline Average Std. Deviation & \multicolumn{4}{|c|}{.42471} \\
\hline
\end{tabular}

As for the (Table 5), the majority of the respondents indicate that they encourage self-employment among other individuals in the society $(79.8 \%, \mu=1.21)$, and this shows that they have a positive attitude towards selfemployment. However, when the students were asked for their opinion towards self-employment as a career choice for them, we found that the percentage decreased by 19 percent $(60.7 \%, \mu=1.42)$ which indicates that there are some issues when it is related to them. However, the average of the two results (average $\mu=1.31$, average mode $=$ 1.00) shows that the students, in general, have positive attitudes towards self-employment. 
The above average results on the students' attitude toward self-employment (mean $=1.389$, median $=1.00$, mode $=1.00 \mathrm{Sd} .=0.42471)$ indicating that the undergraduate students, in general, have positive attitudes toward selfemployment. Thus hypothesis $\mathrm{H} 2$ confirmed.

\subsection{Entrepreneurial intention}

A total of 50 students who indicate that they are already self-employed, within the other of respondents 401 who are not yet self-employed, there are more than two thirds (73.6\%) who have revealed their intention to establish their own business in future. (Table 6) shows the frequencies and percent of respondents' intention to launch business.

Table 6| Entrepreneurial intention $(n=451)$

\begin{tabular}{lccc}
\hline \multicolumn{4}{l}{ Do you intend to launch your own business in the future? } \\
\hline & Frequency & Percentage (\%) & $\begin{array}{c}\text { Valid } \\
\text { Percent (\%) }\end{array}$ \\
\hline Yes & 295 & 65.4 & 73.6 \\
No & 106 & 23.5 & 26.4 \\
Total & 401 & 88.9 & 100 \\
Already self- & 50 & 11 & \\
employed & & & \\
\hline
\end{tabular}

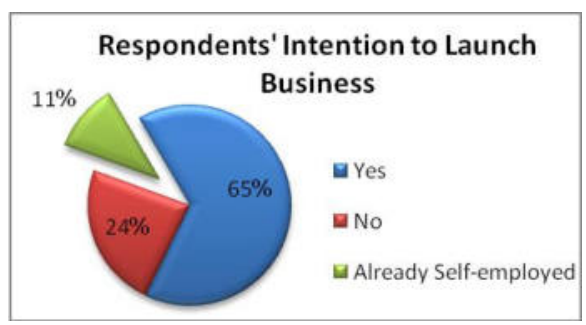

Figure 2| Entrepreneurial intentions

(Table 7) shows the variances of the students' intention within the education and demographic variables. The variances among field of study, year of study and age group variables are statically significant because the P-value is less than the significance level alpha (0.05), which means that these variances are reflecting pattern rather than just chance, whereas the gender variable is not statically significant because the P-value is greater than the significance level alpha (0.05).

Table $7 \mid$ Intention to self-employment within the educational background, gender and age variables $(n=401)$

\begin{tabular}{llccc}
\hline $\begin{array}{l}\text { Do you intend to launch your own } \\
\text { business in the future? }\end{array}$ & Category & $\begin{array}{c}\text { Yes } \\
(\%)\end{array}$ & $\begin{array}{l}\text { No } \\
(\%)\end{array}$ & P-value \\
\hline Field of study & Business programs & 88.2 & 11.8 & \multirow{2}{*}{$000<.05$} \\
& Non-business programs & 39.8 & 60.2 & .0 \\
\hline Year of study & $1^{\text {st }}$ year & 52.1 & 47.9 & \\
& $2^{\text {nd }}$ year & 77.3 & 22.7 & $.000<.05$ \\
& $3^{\text {rd }}$ year & 81.3 & 18.8 & \\
\hline Gender & $4^{\text {th }}$ year & 89.9 & 10.1 & \\
& Male & 73.2 & 26.8 & $.704>.05$ \\
\hline Age group $(\boldsymbol{n}=\mathbf{3 2 3})$ & Female & 75.3 & 24.7 & \\
& $(17-21$ Years $)$ & 65 & 35 & \\
& $(22-26$ Years $)$ & 82 & 18 & $.003<.05$ \\
\hline
\end{tabular}

\subsubsection{Entrepreneurial motives of the respondents}

As for the below (Table 8) the high financial return from the business gets the highest percentage $(52.5 \%)$ as a motivating factor for the students to have the intention to establish their own business, followed by the high rate of unemployment $(45.4 \%) .(42 \%)$ of the respondents indicate that they would like to have their own business as they possess the needed experience and knowledge to start and manage a business. $(36.9 \%)$ of the respondents have been motivated because the community considers self-employment as a good career choice. Only (33.2\%) of the respondent are motivated because they can seize good opportunities in their local market. 
Table 8| Respondents' motivating factors to launch a business $(n=295)$

\begin{tabular}{lcc}
\hline Statements & Frequency & $\begin{array}{c}\text { Percentage } \\
(\%)\end{array}$ \\
\hline There are good opportunities in the local market & 98 & 33.2 \\
I possess the experience and knowledge to start an manage a business & 124 & 42 \\
The financial return of the businesses is high & 155 & 52.5 \\
The community considers self-employment as a good career choice & 109 & 36.9 \\
$\begin{array}{l}\text { With the high unemployment rate, I don't have another option to earn } \\
\text { money }\end{array}$ & 134 & 45.4 \\
\hline
\end{tabular}

\subsection{Social norms}

The results in (Table 9) show to which extent the social norms can affect the students to take the decision of launching a business. The majority of the students $(83 \%, \mu=1.24)$ who are not employed indicate that their families' members have strong effect on their decision, followed by the close friends $(51 \%, \mu=1.61)$, business experts (41.5\%, $\mu=1.77)$, and advisors/consultants $(39 \%, \mu=1.83)$. The colleagues $(63.4 \%, \mu=1.99)$ and relative/acquaintances $(56.3 \%, \mu=2.07)$ get the highest percentage of weak effect, whereas $(25.4 \%, \mu=2.07)$ of the students indicate that the relatives have no effect on their decision to start business.

Table 9| The effects of social norms on non-self-employed respondents

\begin{tabular}{|c|c|c|c|c|c|c|c|c|c|c|c|c|}
\hline & \multirow{2}{*}{\multicolumn{2}{|c|}{$\begin{array}{c}\begin{array}{c}\text { Family } \\
\text { members }\end{array} \\
n=399\end{array}$}} & \multirow{2}{*}{\multicolumn{2}{|c|}{$\begin{array}{c}\text { Close } \\
\text { friends } \\
n=396\end{array}$}} & \multicolumn{2}{|c|}{ Colleagues } & \multicolumn{2}{|c|}{ Relatives } & \multicolumn{2}{|c|}{$\begin{array}{c}\text { Business } \\
\text { experts }\end{array}$} & \multicolumn{2}{|c|}{$\begin{array}{l}\text { Advisor/ } \\
\text { consultant }\end{array}$} \\
\hline & & & & & $n=$ & 96 & $n=$ & 94 & $n=$ & 93 & $n=$ & 92 \\
\hline & Freq. & $\%$ & Freq. & $\%$ & Freq. & $\%$ & Freq. & $\%$ & Freq. & $\%$ & Freq. & $\%$ \\
\hline $\begin{array}{l}\text { 1- Strong } \\
\text { effect }\end{array}$ & 331 & 83 & 202 & 51 & 73 & 18.4 & 72 & 18.3 & 163 & 41.5 & 154 & 39.3 \\
\hline 2- Weak effect & 38 & 9.5 & 144 & 36.4 & 251 & 63.4 & 222 & 56.3 & 155 & 39.4 & 148 & 37.8 \\
\hline 3- No effect & 30 & 7.5 & 50 & 12.6 & 72 & 18.2 & 100 & 25.4 & 75 & 19.1 & 90 & 23 \\
\hline Mean & \multicolumn{2}{|c|}{1.2456} & \multicolumn{2}{|c|}{1.6162} & \multicolumn{2}{|c|}{1.9975} & \multicolumn{2}{|c|}{2.0711} & \multicolumn{2}{|c|}{1.7761} & \multicolumn{2}{|c|}{1.8367} \\
\hline Median & \multicolumn{2}{|c|}{1.0000} & \multicolumn{2}{|c|}{1.0000} & \multicolumn{2}{|c|}{2.0000} & \multicolumn{2}{|c|}{2.0000} & \multicolumn{2}{|c|}{2.0000} & \multicolumn{2}{|c|}{2.0000} \\
\hline Mode & \multicolumn{2}{|c|}{1.00} & \multicolumn{2}{|c|}{1.00} & \multicolumn{2}{|c|}{2.00} & \multicolumn{2}{|c|}{2.00} & \multicolumn{2}{|c|}{1.00} & \multicolumn{2}{|c|}{1.00} \\
\hline Std. Deviation & \multicolumn{2}{|c|}{.58009} & \multicolumn{2}{|c|}{.70019} & \multicolumn{2}{|c|}{.60587} & \multicolumn{2}{|c|}{.65772} & \multicolumn{2}{|c|}{.74624} & \multicolumn{2}{|c|}{.77286} \\
\hline Minimum & \multicolumn{2}{|c|}{1.00} & \multicolumn{2}{|c|}{1.00} & \multicolumn{2}{|c|}{1.00} & \multicolumn{2}{|c|}{1.00} & \multicolumn{2}{|c|}{1.00} & \multicolumn{2}{|c|}{1.00} \\
\hline Maximum & \multicolumn{2}{|c|}{3.00} & & & & & & & & & & \\
\hline
\end{tabular}

In (Table 10) the majority of self-employed students $(77.6 \%, \mu=1.32)$ also indicates that their families' members have a strong effect on their decision to establish a business, followed by experts from the business field $(53 \%, \mu=$ 1.73). The close friends $(46.8 \%, \mu=1.93)$, colleagues $(43.5 \%, \mu=2.04)$ and relative/ acquaintances $(47.8 \%, \mu=$ $2.08)$ get the highest percentage of weak effect, whereas the advisors/consultants $(62.8 \%, \mu=2.34)$ get the highest percentage of no effect.

Table 10| The effects of social norms on self-employed respondents

\begin{tabular}{|c|c|c|c|c|c|c|c|c|c|c|c|c|}
\hline & \multirow{2}{*}{\multicolumn{2}{|c|}{$\begin{array}{c}\begin{array}{c}\text { Family } \\
\text { members }\end{array} \\
n=49\end{array}$}} & \multirow{2}{*}{\multicolumn{2}{|c|}{$\begin{array}{c}\text { Close } \\
\text { friends } \\
n=47\end{array}$}} & \multicolumn{2}{|c|}{ Colleagues } & \multicolumn{2}{|c|}{ Relatives } & \multicolumn{2}{|c|}{$\begin{array}{l}\text { Business } \\
\text { experts }\end{array}$} & \multicolumn{2}{|c|}{$\begin{array}{c}\text { Advisor/ } \\
\text { consultant }\end{array}$} \\
\hline & & & & & & & & & & & & \\
\hline & Freq. & $\%$ & Freq. & $\%$ & Freq. & $\%$ & Freq. & $\%$ & Freq. & $\%$ & Freq. & $\%$ \\
\hline $\begin{array}{l}\text { 1- Strong } \\
\text { effect }\end{array}$ & 38 & 77.6 & 14 & 29.8 & 12 & 26.1 & 10 & 21.7 & 24 & 53.3 & 12 & 27.9 \\
\hline 2- Weak effect & 6 & 12.2 & 22 & 46.8 & 20 & 43.5 & 22 & 47.8 & 9 & 20 & 4 & 9.3 \\
\hline 3- No effect & 5 & 10.2 & 11 & 23.4 & 14 & 30.4 & 14 & 30.4 & 12 & 26.7 & 27 & 62.8 \\
\hline Mean & \multicolumn{2}{|c|}{1.3265} & \multicolumn{2}{|c|}{1.9362} & \multicolumn{2}{|c|}{2.0435} & \multicolumn{2}{|c|}{2.0870} & \multicolumn{2}{|c|}{1.7333} & \multicolumn{2}{|c|}{2.3488} \\
\hline Median & \multicolumn{2}{|c|}{1.0000} & \multicolumn{2}{|c|}{2.0000} & \multicolumn{2}{|c|}{2.0000} & \multicolumn{2}{|c|}{2.0000} & \multicolumn{2}{|c|}{1.0000} & \multicolumn{2}{|c|}{3.0000} \\
\hline Mode & \multicolumn{2}{|c|}{1.00} & \multicolumn{2}{|c|}{2.00} & \multicolumn{2}{|c|}{2.00} & \multicolumn{2}{|c|}{2.00} & \multicolumn{2}{|c|}{1.00} & \multicolumn{2}{|c|}{3.00} \\
\hline Std. Deviation & \multicolumn{2}{|c|}{.65789} & \multicolumn{2}{|c|}{.73438} & \multicolumn{2}{|c|}{.75884} & \multicolumn{2}{|c|}{.72499} & \multicolumn{2}{|c|}{.86340} & \multicolumn{2}{|c|}{.89665} \\
\hline Minimum & \multicolumn{2}{|c|}{1.00} & \multicolumn{2}{|c|}{1.00} & \multicolumn{2}{|c|}{1.00} & \multicolumn{2}{|c|}{1.00} & \multicolumn{2}{|c|}{1.00} & \multicolumn{2}{|c|}{1.00} \\
\hline Maximum & \multicolumn{2}{|c|}{3.00} & & & & & & & & & & \\
\hline
\end{tabular}




\subsubsection{Pearson correlation coefficient}

(Table 11) shows the correlation matrix between the dependent variable (self-employment intention) and independent variables (entrepreneurial awareness, attitude and social norms). The results revealed selfemployment intention had a significant and positive correlation with entrepreneurial awareness $(r=.338, n=401$, $\mathrm{P}<.001)$ and attitude $(r=.569, n=401, \mathrm{P}<.001)$. Whereas, the social norms variable has derived low and a not significant correlation value $(r=.066, n=373, \mathrm{P}>.20)$ with the students' intention.

Table 11. Pearson correlation inter-correlations among dependent and independents variables

\begin{tabular}{|c|c|c|c|c|c|}
\hline Variable & & 1 & 2 & 3 & 4 \\
\hline \multirow{3}{*}{$\begin{array}{l}\text { Self-employment } \\
\text { intention }\end{array}$} & Pearson & & & & \\
\hline & Correlation & 1.00 & & & \\
\hline & Sig. (2-tailed) & & & & \\
\hline \multirow{3}{*}{$\begin{array}{l}\text { Entrepreneurial } \\
\text { awareness }\end{array}$} & Pearson & $338 * *$ & & & \\
\hline & Correlation & $\begin{array}{c}.358 \cdots \\
000\end{array}$ & 1.00 & & \\
\hline & Sig. (2-tailed) & & & & \\
\hline \multirow[t]{3}{*}{ Attitude } & Pearson & & $259 * *$ & & \\
\hline & Correlation & 000 & 8000 & 1.00 & \\
\hline & Sig. (2-tailed) & & & & \\
\hline \multirow[t]{3}{*}{ Social norms } & Pearson & & .093 & & \multirow{3}{*}{1.00} \\
\hline & Correlation & .000 & .072 & (10) & \\
\hline & Sig. (2-tailed) & .204 & $.0 / 2$ & .002 & \\
\hline
\end{tabular}

** Correlation is significant at the 0.01 level (2-tailed)

4.6.2 Binary logistic regression

The binary logistic regression is used when there is a set of independent variables and one dependent variable with two values (dichotomous). In this study, the logistic regression test was performed on the three independent variables as predictors of self-employment intention.

Table 12| Logistic regression - Predictors of self-employment intention

\begin{tabular}{|c|c|c|c|c|c|c|}
\hline Factors & $\beta$ & S.E. & Wald & Df & Sig. & $\operatorname{Exp}(B)$ \\
\hline $\begin{array}{l}\text { Entrepreneurial } \\
\text { Awareness }\end{array}$ & 2.154 & .540 & 15.915 & 1 & .000 & 8.616 \\
\hline Attitude & 3.117 & .382 & 66.505 & 1 & . 000 & 22.572 \\
\hline Social norms & -.153 & .468 & .107 & 1 & .744 & .858 \\
\hline Constant & -9.095 & 1.461 & 38.730 & 1 & .000 & .000 \\
\hline $\begin{array}{l}\text { Nagelkerke } R^{2} \\
\text { Hosmer and Lemeshow }\end{array}$ & $\begin{array}{l}.486 \\
.221 \\
\end{array}$ & & & & & \\
\hline \multirow[t]{2}{*}{ Groups } & \multicolumn{5}{|c|}{$\begin{array}{l}\text { Predicted } \\
\text { ployment intention }\end{array}$} & \\
\hline & & No & & Yes & & Correct \% \\
\hline \multirow[t]{2}{*}{ Self-employment intention } & No & 54 & & 48 & & 52.9 \\
\hline & Yes & 13 & & 258 & & $\begin{array}{l}95.2 \\
83.6\end{array}$ \\
\hline
\end{tabular}

As shown in (Table 12), the Hosmer-Lemeshow statistics is $(0.221)$ which is greater than 0.05 and this indicates that the model adequately fits the data. In other words, it indicates that this model is appropriate for modeling the self-employment intention. The Nagelkerke $R^{2}$ value implies that (48.6\%) of the variation in the dependent variable could be explained by the independent variables in this model which means there are also other factors that have not been considered in this study.

The results show that both variables entrepreneurial awareness $(\beta=2.154, p<0.005)$ and attitude $(\beta=3.117, p<$ $0.005)$ are significantly correlated with the students' intention to start a business, whereas there is not significant correlation between the social norms $(\beta=-0.153, \mathrm{p}>0.744)$ and the students' intention to start a business. The predication success information shows that the model successfully classified the launch of new ventures by $(83.6 \%)$ of respondents. 
Based on the correlation and regression tests conducted, the following could be derived: i) Correlation Significance $=0.204$ indicates that there could be other factors that may have influence on the student's intention to be selfemployed other than the social norms. ii) Regression Significance $=0.744$ indicates that there is no significant correlation between the social norms and the students' intention to be self-employed. Therefore, it can be inferred that there is insufficient evidence to suggest that social norms have a significant influence on undergraduate students' intention to launch a business.

\section{Findings and Discussion}

The goal of this study was to analyze three sets of conditions under which attitude towards self-employment might be most effective for the intention to launch a new venture. We analyzed the entrepreneurial awareness, attitude towered self-employment and social norms. We found the majority of the respondents were business and economics students $220(48.8 \%)$ while the rest were in non-business programs $231(51.2 \%)$ such as sciences, computer and IT, agriculture, law and art. These proportions were as a result of not only the random sampling but also the fact that business and economics students are the majority at the public universities (Mwiya et al., 2017; Sesen, 2013). A total of 378 (83.8\%) of the respondents were male comparing with $73(16.2 \%)$ female, this fact is related to a complex mix of barriers to female education in a patriarchal and tribal society like Yemen. However, both female $(75.3 \%)$ and male $(73.2 \%)$ respondents have almost the same percentage on entrepreneurial intention. Meaning that if woman were allowed to actively participate in the workforce, they can contribute to the overall economic development of a nation. In terms of field of study and entrepreneurial intention, entrepreneurial education is seen as a strong antecedent for entrepreneurial intention. The majority of non-business programs students have no entrepreneurial intention (60.2\%) comparing with the business students (11.8\%). That means that entrepreneurial education improves creativity and provides the necessary skills and mindset to recognize and exploit business opportunities (Lüthje and Franke, 2004; Dickson et al., 2008; Liñán Francisco, 2008; Gürel et al., 2010; Maresch, et al., 2016). Therefore, education and training initiatives trying to increase entrepreneurial potential in the non-business programs students should include workshops specifically addressed to the development of their entrepreneurial skills. The result shows that the entrepreneurial intention increases with the final year students, this group of students is facing important career decisions on completion of their studies of which entrepreneurship could be designated for them. Age also may predict entrepreneurial potential, we found that the entrepreneurial intentions' percentage was increased when the age category goes higher, (22 - 26 years) gets the highest percentage (82\%). Evidence supporting a relationship between age and entrepreneurship is reported by (GEM Report 2018/1019; Henley A., 2007). In contrast, (Hatak et al., 2015) reported a negative relationship between age and entrepreneurial intention. According to (Kautonen, 2008; Lévesque and Minniti, 2006; Hart et al., 2004; Fung et al., 2001), , older people are reluctant to invest in time taking activities with uncertain returns than younger people hence they have lower entrepreneurial intention.

In terms of motivated to start a business, several studies conclude that people's motivations to start a business is often complex and multi-faceted and varies from country to country (Gabrielsson and Politis, 2011, Marlow and Strange, 1994; Shane et al., 1991). In our study, the high financial return from the self-employment gets the highest percentage $(52.5 \%)$ as a motivating factor for students to have the intention to establish their own business, followed by the high rate of unemployment $(45.5 \%)$. From the findings, we observed that the majority of respondents in the current study are perceived to be motivated to start their businesses out of economic necessity rather than free choice. Thus, in developing countries, many nascent entrepreneurs engaged in entrepreneurial activities driven by necessity (Kennedy, et al. 2003; Cañares, 2011; Devece et al., 2016). In contrast, in advanced countries, entrepreneurial careers are in most cases chosen in free will (Olomi, 2009; Benzing and Chu, 2009). However, if we want to learn more about entrepreneurship, we need more studies on entrepreneurial motivation (Carsrud and Brannback, 2011).

The first objective of this study was to focus to identify the level of entrepreneurial awareness and knowledge among undergraduate students. Our findings provided evidence that more than two thirds of undergraduate students never heard or read about the entrepreneurship concept, only $(26.8 \%)$ of all respondents indicated that they had a good level of entrepreneurial awareness. In fact, due to professional characteristics, non-business programs students have fewer opportunities to practice with theoretical knowledge; this is not conducive to the internalization of entrepreneurship and entrepreneurial effective practice. In summary, the existing entrepreneurial awareness education is still relatively inaccessible among undergraduate students, the university education is still a single teacher-based and entrepreneurship education is not high, thus, it is not conducive the transformation of entrepreneurial awareness to entrepreneurial practice. 
In terms of attitude towards self-employment as a career of choice, we found that undergraduate students have positive attitude towards self-employment. Around (80\%) of the respondents encourages self-employment among other individuals in society. However, when the students are asked about their opinion towards self-employment as a career choice for them, we found that the percentage decreased by (19\%). This may give us a hint that there are some issues when it is related to them. The results also show that there is a positive correlation between attitudes, year of study, and age. As whenever the year of study and age are higher their attitude becomes more positive (GEM).

The objective three in this research was to study the influences of social norms on undergraduate students' intention to launch a new venture. Outcomes confirm there is no significant influence of social norms on undergraduate students to launch a business. Our findings are similar with (Krueger et al., 2000; Autio et al., 2001; Liñán and Chen, 2009) who reported no significant impact of subjective norms on entrepreneurial intentions. The majority of students pointed out that their families and close friends are considered as important sources of advice, support, new entrepreneurial ideas and have the strongest effect on their decisions to launch a business. On the contrary, most of the students indicated that the advisor/consultant and relatives are less considered as a source of advice, support, and new entrepreneurial ideas. Likewise, it is noted that the business experts are considered an important source for counseling and new entrepreneurial ideas, the students indicated that the business experts have a strong effect on them to start a business. Similar, most of the self-employed students indicated that they have been encouraged to launch their businesses by experts from the business field. Also, it is worth mentioning that the students have less orientation for getting advice and support from the academic advisors/consultants.

\section{Conclusions}

The majority of students pointed out that their families and close friends (strong ties relationship) are considered as important sources of advice, support and new entrepreneurial ideas. In addition, the students noted that stronger ties have the strongest effect on their decisions to launch a business. On the contrary, most students indicated that the relatives and advisor/consultant are less considered as a source of advice, support and new entrepreneurial ideas and also have no effect on them. However, we could not found a significant correlation between social norms and the students' intention to be self-employed. Our study suggested that providing entrepreneurial capabilities among citizens might improve societal norms toward entrepreneurship.

\section{Acknowledgments}

Authors are thankful to the respondents who devoted their time generously to fill out the questionnaires. Our appreciation is also extended to the editor and anonymous reviewers of Research on Humanities and Social Sciences. We are also thankful to all those who offered information and advice on the issue of attitudes of undergraduate students towards self-employment in Yemen and China public universities.

\section{References}

Adusei, M. (2016). Does entrepreneurship promote economic growth in Africa? African Development Review, 28(2): p. 201-214.

Ajzen, I., \& Fishbein, M., Understanding attitudes and predicting social behavior. Englewood Cliffs: PrenticeHall., 1980.

Aloulou, W.j. (2016). Predicting entrepreneurial intentions of final year Saudi university business students by applying the theory of planned behavior. Journal of Small Business and Enterprise Development, 23(4), pp: $1142-1164$.

Al-Shammari, M., Waleed, R. (2018). Entrepreneurial intentions of private university students in the kingdom of Bahrain. International Journal of Innovation Science, 10(1), pp:43-57.

André, v.S., Martin, Carree., Roy, Thurik. (2005). The Effect of Entrepreneurial Activity on National Economic Growth. Small Business Economics, 24(3): pp. 311-321.

Autio, E., Keeley, R.H., Klofsten, M., Parker, G. and Hay, M. (2001). Entrepreneurial intent among students in Scandinavia and in the USA. Enterprise and Innovation Management Studies, 2(2): pp. 145-160.

Benzing, C., Chu, H.M. and Kara, O. (2009). Entrepreneurs in Turkey: A factor analysis of motivations, success factors, and problems. Journal of small business management, 47(1), pp.58-91. 
Bruce Mwiya, Y.W., Chanda Shikaputo, Bernadette Kaulungombe, Maidah Kayekesi (2017). Predicting the Entrepreneurial Intentions of University Students: Applying the Theory of Planned Behaviour in Zambia, Africa. Open Journal of Business and Management, 5: pp. 592-610.

Cañares, M.P. (2011). In violence as in peace: violent conflict and rural entrepreneurship in the Philippines. Journal of Small Business\& Entrepreneurship, 24(2): pp. 253-264.

Carsrud, A. and Brännback, M. (2011). Entrepreneurial motivations: what do we still need to know. Journal of Small Business Management, 2011. 49(1): pp. 9-26.

Crant, J. (1996). The proactive personality scale as a predictor of entrepreneurial intentions. Journal of Small Business Management, 34(3): pp. 42-49.

Davidsson, P. (1995). Determinants of entrepreneurial intentions. Jonskoping International Business School.

Debus, M., Tosun, J. and Maxeiner, M. (2017). Support for policies on entrepreneurship and selfemployment among parties and coalition governments. Politics and Policy, 45(3): pp. 338-371.

Devece, C., Peris-Ortiz, M. and Rueda-Armengot, C. (2016). Entrepreneurship during economic crisis: success factors and paths to failure. Journal of Business Research, 69(11): pp. 5366-5370.

Dickson, P.H., Solomon, G.T. and Weaver, K.M. (2008). Entrepreneurial selection and success: does education matter? Journal of Small Business and Enterprise Development, 15(2): pp. 239-258.

Douglas, E., Shepherd, AD. (2002). Self-employment as a career choice: attitudes, entrepreneurial intentions, and utility maximization. Entrepreneurship Theory and Practice, 26(3): pp. 81-91.

Engle, R.L., Dimitriadi, N., Gavidia, J. V., Schlaegel, C., Delanoe, S., Alvarado, I., He, X., Buame, S., \& Wolff, B. (2010). Entrepreneurial intent: a twelve-country evaluation of Ajzen's model of planned behavior. International Journal of Entrepreneurial Behaviour and Research, 16(1): pp. 36-58.

Fung, H.H., Lai, P. and Ng, R. (2001). Age differences in social preferences among Taiwanese and Mainland Chinese: the role of perceived time. Psychology and Aging, 16(2): pp. 351-356.

Gabrielsson, J. and Politis, D. (2011). Career motives and entrepreneurial decision-making: examining preferences for causal and effectual logics in the early stage of new ventures. Small Bus Economics, 36(3): pp. 281298.

Gnyawali, Devi R Fogel, Daniel S. (1994). Environments for entrepreneurship development: Key dimensions and research implications. Entrepreneurship Theory and Practice, 18(4): pp. 43-62.

Gürel, E., Altinay, L. and Daniele, R. (2010). Tourism students' entrepreneurial intentions. Annals of Tourism Research, 37(3): pp. 646-669.

Harshana, K. (2016). Investigating the impact of entrepreneurship on economic development: a regional analysis. Journal of Small Business and Enterprise Development, 23(3): pp. 869-916.

Hart, M., Anyadike-Danes, M. and Blackburn, R., (2004). Entrepreneurship and age in the UK: Comparing third age and prime age new venture creation across the regions. REnT xvIII, Copenhagen, pp.25-26.

Hatak, I., Harms, R. and Fink, M. (2015). Age, job identification and entrepreneurial intention. Journal of Managerial Psychology, 30(1): pp. 38-53.

Henley, A. (2007). Entrepreneurial Aspiration and Transition into Self-Employment: Evidence from British Longitudinal Data. Entrepreneurship \& Regional Development, 19(3): p. 253-280.

Kautonen, T. (2008). Understanding the older entrepreneur: comparing third age and prime age entrepreneurs in Finland. International Journal of Business Science and Applied Management, 3(3): pp. 3-13.

Kennedy, J., Drennan, J., Renfrow, P. and Watson, B. (2003). Situational factors and entrepreneurial intentions. In Proceedings of SEAANZ 2003 Conference. University of Ballarat (Online), https://eprints.qut.edu.au/26752/1/c26752.pdf

Kolvereid, L. (1996a). Organizational employment versus self-employment: reasons for career intentions. Entrepreneurship: Theory and Practice, 30(3): pp. 23-31. 
Kolvereid, L. (1996b). Prediction of employment status choice intentions. Entrepreneurship: Theory and Practice, 21(1): pp. 47-57.

Kolvereid, L., \& Isaksen, E. (2006). New business start-up and subsequent entry into self-employment. Journal of Business Venturing, 21(6): pp. 866-885.

Kristiansen, S. and Indarti, N. (2004). Entrepreneurial intention among Indonesian and Norwegian students. Journal of Enterprising Culture, 12(1), pp. 55-78.

Krueger Jr., N.F., Reilly, M.D., Carsrud, A.L. (2000). Competing models of entrepreneurial intentions. Journal of Business Venturing, 15(5-6): pp. 411-432.

Lévesque, M. Minniti, M. (2006). The effect of aging on entrepreneurial behaviour. Journal of Business Venturing, 21(2): pp. 177-194.

Liñán, F. (2008). Skill and value perceptions: how do they affect entrepreneurial intentions? International Entrepreneurship and Management Journal, 4(3): pp. 257-272.

Liñán, F., Chen, Y.-W. (2009). Development and cross-cultural application of a specific instrument to measure entrepreneurial intentions. Entrepreneurship Theory and Practice, 33(3): pp. 593-617.

Liñán, F.R.-C., J.C.; Rueda-Cantuche, J.M. (2011). Factors Affecting Entrepreneurial Intention Levels: A Role for Education. International Entrepreneurship and Management Journal, 7(2): pp. 195-2018.

Lüthje, C.a.F., N. (2014). Entrepreneurial intentions of business students: a benchmarking study. International Journal of Innovation and Technology Management, 1(3): pp. 269-288.

Malebana, J. (2017). Knowledge of entrepreneurial support and entrepreneurial intention in the rural provinces of South Africa. Development Southern Africa, 34(1), pp. 74-89.

Maresch, D., Harms, R., Kailer, N., Wimmer-Wurm, B. (2016). The impact of entrepreneurship education on the entrepreneurial intention of students in science and engineering versus business studies university programs. Technological Forecasting \& Social Change, 104: pp. 172-179.

Maria, S., \& Allam, Hamdan (1019). The moderating role of governmental support in the relationship between entrepreneurship and economic growth A study on the GCC countries. Journal of Entrepreneurship in Emerging Economies, 11(2): p. 200-216.

Marlow, S. and Strange, A. Female entrepreneurs - success by whose standards? Routledge, London, 1994.

Monitor, G.E., 2019. Monitor 2018-2019. (2019). Global Entrepreneurship Research Association (GERA).

North, D.S., D. (2006). Developing entrepreneurship and enterprise in Europe's pheripheral rural areas: Some issues facing policy-makers. European Planning Studies, 14(1): pp. 41-60.

Norusis, M., SPSS 15.0 Statistical Procedures Companion. Chicago: Prentice Hall., 2006.

Olomi, D.R. (2009). African entrepreneurship and small business development: Context and process.

Peslak, A., Ceccucci, W., and Sendall, P. (2012). An Empirical Study of Social Networking Behavior Using Theory of Reasoned Action. Journal of Information Systems Applied Research (JISAR), 5(3): pp.12-23.

Reyad, S., Badawi, S. \& Hamdan, A. (2018). Entrepreneurship and accounting students' career in arab region: conceptual perspective. The Journal of Developing Areas, 52(4): p. 283-288.

Schwarz, E.J., Wdowiak, M.A., Almer-Jarz, D.A. and Breitenecker, R.J. (2009). The effects of attitudes and perceived environment conditions on students' entrepreneurial intent. Education + Training, 51(1): pp. $272-291$.

Sesen, H. (2013). Personality or environment? A comprehensive study on the entrepreneurial intentions of university students. Education + Training, 55(7): pp. 624-640.

Shane, S., Kolvereid, L. and Westhead, P. (1991). An exploratory examination of the reasons leading to new firm formation across country and gender. Journal of Business Venturing, 6(6): pp. 431-446.

Thompson, E.R. (2009). Individual entrepreneurial intent: construct clarification and development of an internationally reliable metric. Entrepreneurship Theory and Practice, 33(3): pp. 669-694. 
Ting, S. X.; Feng, L. and Qin, W. (2017). The effect of entrepreneur mentoring and its determinants in the Chinese context. Management Decision, 55 (7): pp. 1410-1425.

Tkachev, A., Kolvereid, L. (1999). Self-employment intentions among Russian students. Entrepreneurship \& Regional Development, 11(3): pp. 269-280.

Van Gelderen, M., Brand, M., Van Praag, M., Bodewes, W., Poutsma, E., \& Van Gils, A. (2008). Explaining entrepreneurial intentions by means of the theory of planned behaviour. Career Development International, 13(6): pp. 538-559.

Wang, C.K.W., P.K. (2004). Entrepreneurial interest of university students in Singapore. Technovation, 24(2): pp. $163-172$.

Yemane, T., Statistics: an introductory analysis. 2nd edition, New York: Harper and Row, 1967.

Zhang, P., Wang, D. D., Owen, CL. (2015). A study of entrepreneurial intention of university students. Entrepreneurship Research Journal, 5(1): pp. 61-82.

Zheng, L.a.Y., Liu, (2011). Entrepreneurship education and employment performance An empirical study in Chinese university. Journal of Chinese Entrepreneurship, 3(3): pp. 195-203. 